\title{
EMBRIOGENESIS SOMATIK ROTAN TOHITI (Calamus inops Becc. ex Heyne)
}

Somatic embryogenesis of tohiti rattan (Calamus inops Becc. ex Heyne)

\author{
Yelnititis \\ Balai Besar Penelitian dan Pengembangan Bioteknologi dan Pemuliaan Tanaman Hutan \\ Jl. Palagan Tentara pelajar Km. 15, Purwobinangun, Pakem, Sleman, Yogyakarta, Indonesia \\ email: yelnititis@yahoo.com
}

Tanggal diterima: 16 Juni 2017, Tanggal direvisi: 9 Agustus 2017, Disetujui terbit: 18 April 2018

\begin{abstract}
The conventional propagation of tohiti rattan still faces problem because of infrequent fruiting season and limited seed production. Somatic embryogenesis is an alternative technique to solve the problem. The purpose of this experiment is to obtain the best growth regulator treatments for embryogenic callus and somatic embryo formation of tohiti rattan. Murashige and Skoog (MS) basal medium was used as growth medium. The experiment was conducted in three stages: seed germination, embriogenic callus induction and somatic embryo induction. MS medium without plant growth regulator was used for aseptic seed germination. MS medium supplemented with growth regulator of BA (Benzyl adenine) of $0.5-2.0 \mathrm{mg} / \mathrm{l}$ was used for embryogenic callus induction. MS medium supplemented with BA $1.0 \mathrm{mg} / \mathrm{l}$ in combination with hormone 2.4-D of $0.0-1.0 \mathrm{mg} / \mathrm{l}$ was used for somatic embryo induction. The seed germination percentage, visual performance on embryogenic callus and somatic embryo were observed. The results showed that the percentage of aseptically seed germination reached $90 \%$. MS medium supplemented with $1.0 \mathrm{mg} / \mathrm{l} \mathrm{BA}$ is the best media for embryogenic callus induction with friable, white and yellowish of callus which was observed after four months of induction culture. The BA of $1.0 \mathrm{mg} / \mathrm{l}$ in combination with 2.4-D of $1.0 \mathrm{mg} / \mathrm{l}$ provided the highest number of the formed somatic embryo.The performance of somatic embryos formation from this treatment was likely as zygotic embryo.
\end{abstract}

Keywords: Murashige and Skoog, Benzyl adenin, somatic embryo, plantlet

\begin{abstract}
ABSTRAK
Perbanyakan rotan tohiti secara konvensional masih mempunyai beberapa masalah karena musim berbuah yang tidak menentu dan jumlah buah yang terbatas. Salah satu pendekatan yang dapat digunakan untuk memecahkan masalah ini adalah melalui teknologi embriogenesis somatik. Penelitian ini bertujuan untuk mendapatkan zat pengatur tumbuh terbaik pada induksi kalus embriogenik dan induksi embrio somatik rotan tohiti. Media dasar Murashige dan Skoog (MS) digunakan sebagai media tumbuh. Penelitian dilakukan dalam 3 tahap kegiatan, yaitu perkecambahan biji, induksi kalus embriogenik dan induksi embrio somatik. Media MS tanpa penambahan zat pengatur tumbuh digunakan untuk perkecambahan biji secara aseptik. Untuk induksi kalus embriogenik diberikan perlakuan BA (Benzyl adenine) konsentrasi $(0,5-2,0 \mathrm{mg} / \mathrm{l})$ pada media MS. Pada tahap induksi embrio somatik diberikan perlakuan BA $1 \mathrm{mg} / \mathrm{l}$ yang dikombinasikan dengan 2,4-D konsentrasi 0,0-1,0 mg/l. Pengamatan dilakukan terhadap persentase biji berkecambah, penampilan visual kalus embriogenik dan embrio somatik yang dihasilkan. Hasil penelitian menunjukkan bahwa persentase biji yang tumbuh secara aseptik mencapai 90\%. Modifikasi media MS dengan penambahan BA 1,0 mg/l merupakan perlakuan terbaik untuk induksi kalus embriogenik. Kalus embriogenik yang terbentuk mempunyai tekstur remah, berwarna putih bening dan kekuningan pada empat bulan induksi. BA 1,0 mg/l yang dikombinasikan dengan 2,4-D 1,0 mg/l pada media MS memberikan jumlah embrio somatik terbanyak. Embrio somatik diperoleh dari perlakuan ini mempunyai penampilan yang sama seperti embrio zigotik.
\end{abstract}

\section{Kata kunci: Murashige dan Skoog, Benzyl adenine, embrio somatik, plantlet}

\section{PENDAHULUAN}

Rotan merupakan salah satu hasil hutan bukan kayu (HHBK) yang mempunyai nilai ekonomi cukup tinggi sebagai sumber devisa negara yang dalam pemanfaatannya banyak melibatkan petani (Kalima \& Jasni, 2010). Rotan tumbuh secara alami dan tersebar mulai dari daerah pantai sampai pegunungan dengan ketinggian $0-2900$ meter diatas permukaan laut. Secara ekologis rotan tumbuh dengan subur di berbagai tempat, baik dataran rendah maupun agak tinggi terutama di daerah yang lembab (Kalima, 2008).

Indonesia merupakan salah satu negara penghasil rotan terbanyak di dunia dengan 297 
jenis rotan yang termasuk ke dalam 9 marga (Witono, 1999), dimana 50 jenis diantaranya mempunyai nilai ekonomi tinggi. Menurut Pribadi (2012), 85\% produksi rotan dunia berasal dari Indonesia. Namun demikian 90\% kebutuhan masih disuplai dari hutan alam dan hanya $10 \%$ yang berasal dari hasil budidaya rotan (Kalima \& Jasni, 2015). Memperhatikan kondisi ini dalam Permenhut no. 19 tahun 2009 rotan telah ditetapkan sebagai salah satu komoditas HHBK yang pengembangannya perlu dilaksanakan dengan sistem budidaya.

Salah satu jenis rotan yang memiliki nilai ekonomi tinggi adalah rotan tohiti (Calamus inops Becc. ex Heyne). Batang rotan tohiti agak keras dan tidak begitu mudah dibelah-belah sehingga sangat baik digunakan untuk pembuatan mebel, penahan pasir di gurun pasir, sandaran kapal, pengisi batang sepeda, pengganti kerangka baja (Baharuddin \& Taskirawati, 2009). Secara alami jenis ini tumbuh di daerah berbukit dan ditemukan hampir di seluruh daratan Sulawesi. Namun demikian terdapat beberapa kendala dalam budidaya rotan tohiti karena musim berbuah yang tidak menentu dan ketersediaan biji yang semakin menurun. Hal ini karena rotan tohiti tumbuh tunggal dan tidak berumpun sehingga hanya dapat dipanen satu kali. Sementara itu selama ini perbanyakannya hanya dapat dilakukan dengan biji. Pemanenan melalui penebangan batang rotan sebelum masa reproduktif ini akan memutus mata rantai regenerasinya sehingga berakibat buahnya akan semakin jarang diperoleh. Untuk itu upaya perbanyakan tanaman melalui teknologi pembiakan vegetatif baik secara makro maupun mikro melalui budidaya jaringan perlu untuk dilakukan.

Sampai saat ini perbanyakan rotan melalui budidaya jaringan belum banyak dilaporkan. Budidaya jaringan dapat dilakukan melalui tiga cara, yaitu pembentukan tunas aksilar, pembentukan tunas adventif dan embriogenesis somatik. Embriogenesis somatik adalah proses pembentukan embrio dari sel atau jaringan somatik yang dapat berkembang membentuk tanaman normal baru. Zhou et al., (2010) menyatakan bahwa embriogenesis somatik adalah suatu metode perbanyakan vegetatif yang cepat dan efektif. Embriogenesis somatik dapat dilakukan melalui dua cara yaitu secara langsung dan secara tidak langsung. Embriogenesis somatik langsung adalah pembentukan embrio somatik yang langsung dari jaringan eksplan sedangkan embriogenesis somatik tidak langsung adalah pembentukan embrio somatik melalui proliferasi kalus (Hussein, Ibrahim, \& Kiong, 2006). Embriogenesis somatik mempunyai beberapa keuntungan antara lain tingkat multiplikasi yang tinggi, bibit yang dihasilkan seragam dan mudah digunakan pada medium cair sehingga cocok sebagai salah satu teknologi yang perlu dikembangkan dalam budidaya rotan.

Media kultur dan zat pengatur tumbuh (ZPT) yang tepat merupakan komponen penting yang akan mempengaruhi keberhasilan embriogenesis somatik suatu jenis tanaman. Muchtar, Winata, Wattimena, dan Yahya (1997) melaporkan bahwa diantara dua jenis sitokinin yang digunakan, penggunaan BAP (6-Benzylaminopurine) merupakan zat pengatur tumbuh yang paling baik untuk perbanyakan tunas rotan manau. Namun demikian sampai saat ini belum ada penelitian tentang teknik embriogenesis somatik pada budidaya rotan tohiti. Untuk itu penelitian ini dilakukan dalam upaya mendapatkan zat pengatur tumbuh terbaik pada induksi kalus embriogenik dan induksi embrio somatik rotan tohiti. Penelitian diharapkan mampu menghasilkan teknologi perbanyakan melalui budidaya jaringan untuk mendukung sistem budidaya rotan tohiti.

\section{BAHAN DAN METODE}

\section{A. Waktu dan tempat}

Pengambilan buah rotan tohiti dilakukan pada bulan Desember 2015. Penelitian dilaksanakan di Laboratorium Kultur Jaringan Balai Besar Penelitian dan Pengembangan 
Bioteknologi dan Pemuliaan Tanaman Hutan, Yogyakarta dari bulan Januari 2016 sampai bulan Desember 2016.

\section{B. Bahan dan alat}

\section{Bahan}

Bahan tanaman yang digunakan sebagai sumber eksplan diambil dari desa Nopa Bomba, KPHP Dolago Tanggunung, Sulawesi Tengah. Bagian tanaman yang digunakan sebagai sumber eksplan adalah buah rotan tohiti. Jumlah biji rotan tohiti yang digunakan sangat terbatas yaitu sebanyak 162 biji. Bahan kimia yang digunakan sebagai media tumbuh berasal dari komposisi media dasar Murashige dan Skoog (MS) yang diperkaya dengan vitamin B dan agar sebagai pemadat. Adapun zat pengatur tumbuh yang digunakan adalah BA (Benzyladenine) dan 2,4-D.

\section{Alat}

Peralatan yang digunakan dalam penelitian ini antara lain timbangan analitik, hot plate dan magnetic stirrer, alat-alat gelas, $\mathrm{pH}$ meter, botol kultur, alumunium foil, autoklaf, laminar air flow (LAF), pinset, scalpel, gunting, cling wrap, spidol, pensil dan lain-lain.

\section{Prosedur kerja}

Buah rotan tohiti direndam selama dua malam sehingga kulitnya menjadi lunak. Kemudian bijinya dikeluarkan dan dipisahkan dari kulitnya, ditempatkan dalam wadah berisi air dan biji yang tenggelam dalam air digunakan sebagai eksplan. Biji dicuci dengan menggunakan sabun cair lalu dibilas dengan air sampai bersih, diikuti dengan perendaman dalam 1 gram/liter $(0,1 \%)$ larutan fungisida Antracol selama 15 menit dan dibilas dengan air sampai bersih.

Penelitian dilakukan dalam tiga tahap kegiatan, yaitu 1) perkecambahan biji, 2) induksi kalus embriogenik dan 3) induksi embrio somatik.

\section{Perkecambahan biji}

Biji yang sudah dicuci bersih selanjutnya disterilisasi dengan menggunakan alkohol 70\%, Bayclin ${ }^{\circledR}$ 15\% dan $10 \%$ masing-masing selama 5 menit, 10 menit dan 15 menit serta dibilas dengan air steril. Biji yang sudah disterilisasi dikecambahkan pada media dasar MS tanpa penambahan zat pengatur tumbuh dan ditempatkan di ruang gelap. Persentase biji berkecambah dihitung dengan membandingkan jumlah biji yang berkecambah dengan jumlah biji yang dikecambahkan $\times 100 \%$. Kecambah yang dihasilkan dan bebas dari kontaminan dijadikan sebagai eksplan untuk tahapan kegiatan selanjutnya.

\section{Induksi kalus embriogenik}

Pada tahap induksi kalus embriogenik, kecambah yang utuh dan steril berumur dua bulan dengan ukuran 1,5-2,0 cm dipisahkan dari kulit bijinya yang keras (cangkang) kemudian ditumbuhkan pada modifikasi media MS dengan penambahan perlakuan konsentrasi zat pengatur tumbuh sebagai berikut :
a. BA $0,5 \mathrm{mg} / \mathrm{l}$,
b. BA $1,0 \mathrm{mg} / \mathrm{l}$,
c. BA $1,5 \mathrm{mg} / \mathrm{l}$,
d. BA 2,0 mg/l,

Pengamatan dilakukan terhadap tanggap pertumbuhan dan penampilan biakan secara visual. Pengamatan dilakukan setiap 4 minggu sampai umur 20 minggu. Rancangan yang digunakan pada tahap induksi kalus embriogenik adalah Rancangan Acak Lengkap (RAL). Masing-masing perlakuan terdiri dari 10 botol dan masing-masing botol berisi 1 eksplan yang berasal dari satu potong kecambah.

\section{Induksi embrio somatik}

Pada tahap induksi embrio somatik, kalus embriogenik berwarna putih bening yang diperoleh dari perlakuan konsentrasi BA terbaik (BA 1,0 mg/l) ditumbuhkan kembali pada modifikasi media MS yang ditambahkan kombinasi zat pengatur tumbuh BA $1,0 \mathrm{mg} / \mathrm{l}$ 
dengan beberapa konsentrasi zat pengatur tumbuh 2,4-D sebagai berikut:
a. $\mathrm{BA} 1,0 \mathrm{mg} / \mathrm{l}+2,4-\mathrm{D} 0,0 \mathrm{mg} / \mathrm{l}$
b. BA $1,0 \mathrm{mg} / \mathrm{l}+2,4-\mathrm{D} 0,5 \mathrm{mg} / \mathrm{l}$
c. BA $1,0 \mathrm{mg} / \mathrm{l}+2,4-\mathrm{D} 0,75 \mathrm{mg} / \mathrm{l}$
d. BA 1,0 mg/l + 2,4-D 1,0 mg/l.

Pengamatan dilakukan setiap 4 minggu selama 16 minggu. Parameter yang diamati meliputi tanggapan pertumbuhan, jumlah embrio somatik yang dihasilkan dan penampilan visual embrio somatik. Rancangan yang digunakan adalah Rancangan Acak Lengkap (RAL). Masing-masing perlakuan terdiri dari 10 botol dan setiap botol berisi potongan kalus dengan ukuran $1 \times 1 \mathrm{~cm}$. Pada penelitian ini tidak ada ulangan perlakuan karena keterbatasan eksplan kalus yang dihasilkan.

\section{Perkecambahan embrio}

Embrio somatik fase koleoptilar yang diperoleh pada tahap sebelumnya dipisahkan dengan menggunakan scalpel, dan dikecambahkan pada modifikasi media MS dengan perlakuan penambahan zat pengatur tumbuh BA konsentrasi 0,$25 ; 0,5$ dan $0,75 \mathrm{mg} / 1$. Masing-masing perlakuan terdiri dari 7 botol.

\section{Analisis data}

Data hasil penelitian dianalisa dengan analisis sidik ragam dan apabila terdapat perbedaan dilanjutkan dengan DMRT (Duncan Multiple Range Test).

\section{HASIL DAN PEMBAHASAN}

\section{A. Perkecambahan biji}

Hasil penelitian menunjukkan bahwa biji rotan tohiti yang dikecambahkan secara aseptik pada media dasar MS tanpa zat pengatur tumbuh mulai memperlihatkan tanggapan proses perkecambahan pada hari ke-enam setelah tanam. Hasil ini hampir sama dengan perkecambahan benih rotan jernang yaitu pada hari ke-tujuh setelah ditanam (Winarni, Fitriani, Purnomo, \& Panjaitan, 2017). Sedangkan dari penelitian Kusdi dan Muslimin (2008) menunjukkan bahwa kecepatan daya berkecambah benih rotan manau lebih lambat yaitu 36,7 hari setelah tanam.

Tanggapan perkecambahan diawali dengan munculnya calon tunas berwarna putih (Gambar 1a) pada titik tumbuh. Calon tunas secara perlahan bertambah besar diikuti dengan muncul dan memanjangnya akar berjumlah antara 3- 4 buah yang melekat erat pada cangkangnya pada minggu ke-delapan (Gambar $1 \mathrm{~b}$ dan $1 \mathrm{c})$.
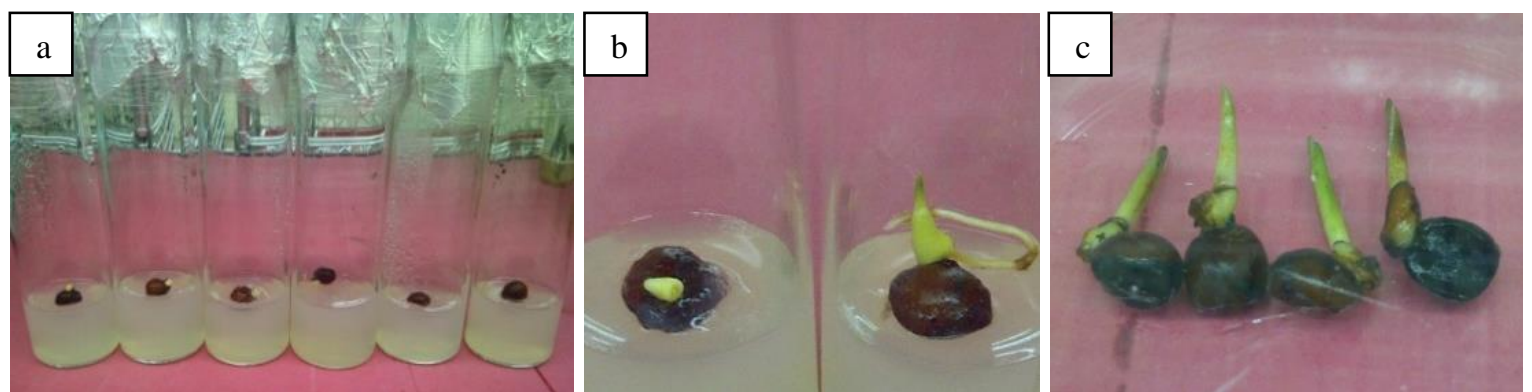

Gambar 1. Proses perkecambahan rotan tohiti secara aseptik pada umur 6 hari (a), 4 dan 8 minggu (b) dan 12 minggu (c)

Dari 162 biji yang dikecambahkan, 94\% diantaranya dapat berkecambah. Namun demikian dari jumlah tersebut hanya $40 \%$ dihasilkan kecambah yang steril, sedangkan $60 \%$ mengalami kontaminasi terutama disebabkan oleh jamur dan juga dijumpai bakteri. Hasil ini lebih baik dibandingkan dengan daya berkecambah rotan manau yaitu sebanyak 83,3\% (Kusdi \& Muslimin, 2008) dan daya berkecambah rotan jernang sebanyak $80 \%$ (Winarni et al., 2017). Kontaminasi yang disebabkan oleh jamur dicirikan dengan adanya 
spora yang berwarna putih atau hitam tergantung pada jenis jamurnya, sedangkan kontaminasi yang disebabkan bakteri dicirikan dengan adanya lendir berwarna putih susu atau kemerahan.

\section{B. Induksi kalus embriogenik}

Penggunaan eksplan yang steril merupakan kunci utama dalam budidaya jaringan. Biakan kecambah kecil dan steril yang diperoleh dari tahap perkecambahan yang sudah berumur 60 hari dan tinggi antara 1,5 $\mathrm{cm}-2,0$ cm dipisahkan dari kulit biji yang keras (cangkang) kemudian ditumbuhkan kembali pada media induksi kalus embriogenik.

Hasil penelitian menunjukkan bahwa penggunaan BA pada konsentrasi yang berbeda memberikan tanggapan yang bervariasi terhadap pertumbuhan kalus (Tabel 1). Eksplan yang ditumbuhkan pada media MS dengan perlakuan penambahan zat pengatur tumbuh BA konsentrasi $\quad 0,5 \quad \mathrm{mg} / \mathrm{l} \quad$ memperlihatkan pertumbuhan yang lebih lambat dan tidak terbentuk kalus (Gambar 2a). Sedangkan eksplan yang ditumbuhkan pada perlakuan BA dengan konsentrasi yang lebih tinggi, yaitu 1,0 $\mathrm{mg} / \mathrm{l}$ sampai 2,0 $\mathrm{mg} / \mathrm{l}$ cenderung memicu terbentuknya kalus (Gambar 2b dan 2c). Hal ini diduga bahwa rotan tohiti mempunyai kandungan auksin endogen yang tinggi. Adanya penambahan sitokinin eksogen pada media tumbuh dan diserap oleh eksplan menyebabkan terjadinya perubahan kandungan hormon endogen dan keseimbangan antara auksin dan sitokinin di dalam jaringan. Kandungan auksin dan sitokinin yang seimbang akan merangsang terbentuknya kalus. Menurut Ikeuchi et al., (2013) kandungan auksin dan sitokinin yang seimbang akan merangsang induksi kalus, konsentrasi auksin yang relatif tinggi akan menginduksi akar dan kandungan sitokinin yang relatif tinggi akan menginduksi tunas.
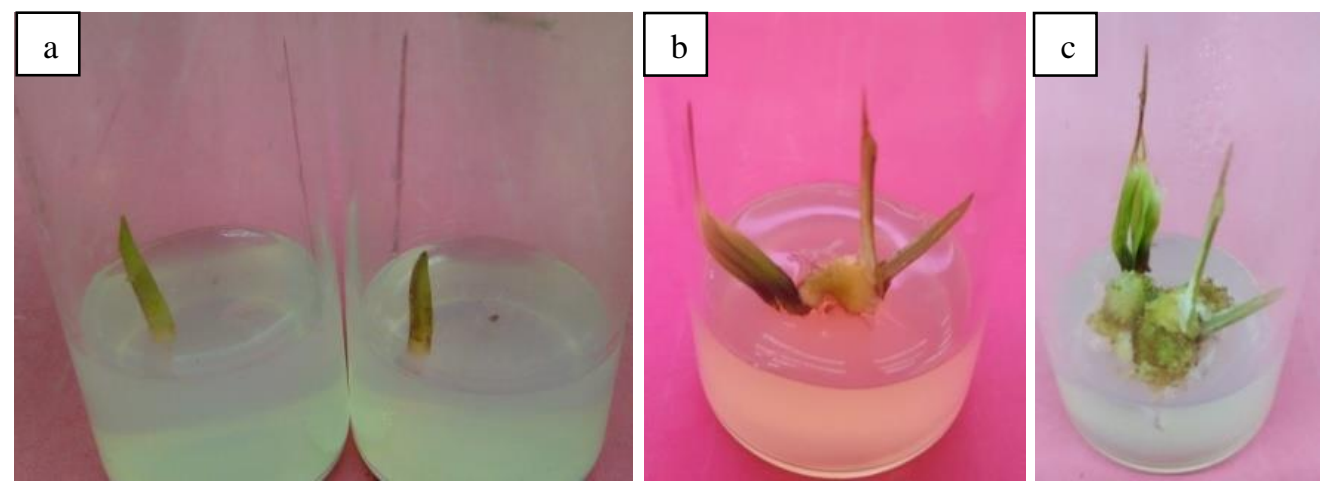

Gambar 2. Perkembangan induksi kalus embriogenik eksplan rotan tohiti umur 8 minggu yang ditumbuhkan pada Media MS dengan penambahan zat pengatur tumbuh BA 0,5 mg/l (a); 1,0-2,0 mg/ 1 (b dan c)

Tanggapan pertama yang teramati pada tahap induksi kalus dari eksplan rotan tohiti adalah terjadinya pembesaran pada bagian pangkal eksplan yang ditumbuhkan. Hal ini disebabkan karena terjadinya proses pembelahan sel akibat adanya penambahan zat pangatur tumbuh BA ke dalam media tumbuh yang digunakan. BA merupakan zat pengatur tumbuh kelompok sitokinin yang berperan dalam induksi tunas, pertumbuhan dan perkembangan tanaman seperti pembelahan sel jika dikombinasikan dengan auksin (Lestari, 2011; Anniasari, Putri, \& Muliawati, 2016). Pada penelitian ini penggunaan BA berperan dalam induksi kalus. Vondráková, Krajňáková, Fischerová, Vágner, dan Eliášová (2016) menyatakan bahwa sitokinin dibutuhkan untuk induksi kultur embriogenik pada beberapa spesies tanaman.

Dalam penelitian ini kalus mulai terbentuk pada 7 - 10 minggu setelah eksplan ditumbuhkan. Kalus hanya terbentuk pada 
bagian pangkal eksplan yang menyentuh media yang langsung menyerap nutrisi (Gambar 2b). Disamping itu pangkal eksplan merupakan bagian meristem yang mudah diinduksi dengan adanya perlakuan penambahan zat pengatur tumbuh.

Tabel 1. Persentase pembentukan dan kenampakan visual kalus pada induksi kalus embriogenetik eksplan rotan tohiti dengan perlakuan zat pengatur tumbuh BA sampai umur 17 minggu

\begin{tabular}{ccc}
\hline Perlakuan $(\mathrm{mg} / \mathrm{l})$ & Induksi kalus $(\%)$ & Visual kalus yang terbentuk \\
\hline BA 0,5 & 0 & Tidak terbentuk kalus \\
BA 1,0 & 50 & Kalus remah, embriogenik, warna putih bening \\
BA 1,5 & 20 & Kalus kompak, warna kehijauan \\
BA 2,0 & 20 & Kalus kompak, warna kehijauan \\
\hline
\end{tabular}

Persentase eksplan rotan tohiti yang dapat membentuk kalus pada penelitian ini adalah $0 \%$ - 50\% (Tabel 1). Induksi kalus paling tinggi dihasilkan dari perlakuan BA $1,0 \mathrm{mg} / \mathrm{l}$, yaitu sebanyak 50\%. Menurut Eshraghi, Zarghami, dan Mirabdulbaghi (2005) perlakuan dan jenis zat pengatur tumbuh yang berbeda memberikan pengaruh yang berbeda terhadap induksi kalus. Selain menghasilkan persentase pembentukan kalus paling tinggi, perlakuan BA 1,0 mg/l juga merupakan perlakuan terbaik untuk penampilan visual kalus yang terbentuk dimana kalus yang dihasilkan mempunyai tekstur remah dan berwarna putih bening dengan sel-sel berukuran kecil dan permukaan sel-selnya halus (Gambar 3a). Hasil yang sama dilaporkan oleh Zang et al., (2016) bahwa perlakuan terbaik untuk kualitas kalus adalah penggunaan penambahan zat pengatur tumbuh BA $1,0 \mathrm{mg} / \mathrm{l}$. Dilihat dari kenampakan visualnya, kalus yang dihasilkan dari perlakuan ini merupakan kalus embriogenik. Oetami (2015) menyatakan bahwa kalus embrionik dicirikan dengan tekstur remah dan mudah dipisahkan. Selanjutnya Rusdianto dan Indrianto (2012) melaporkan bahwa kalus embriogenik umumnya berwarna putih bening atau putih kekuningan dan remah. Pengaruh efektivitas penambahan zat pengatur tumbuh BA pada induksi kalus embriogenik juga telah dilaporkan pada beberapa jenis tanaman. Puhan dan Rath (2012) melaporkan bahwa kalus embriogenik dari eksplan bibit Desmodium gangeticum L., dapat terbentuk dari perlakuan BA dengan konsentrasi 0,5 mg/l. Zhou et al., (2010) juga melaporkan bahwa perlakuan BA dengan konsentrasi $0,5 \mathrm{mg} / \mathrm{l}$ dikombinasikan dengan kinetin 0,2 $\mathrm{mg} / \mathrm{l}$ menghasilkan kalus granular, remah dan berwarna kekuningan.

\section{Induksi embrio somatik}

Induksi embrio somatik dilakukan dengan menggunakan eksplan kalus yang dihasilkan pada tahap induksi kalus embriogenik. Kalus embriogenik yang diperoleh pada tahap induksi dari perlakuan BA 1,0 mg/l dilakukan subkultur secara berulang pada perlakuan yang sama untuk mendapatkan jumlah kalus embriogenik yang mencukupi. Kalus selanjutnya dipindahkan dan ditumbuhkan pada media induksi embrio somatik.

Secara umum perlakuan pada media induksi embrio somatik rotan tohiti menunjukkan perbedaan yang nyata terhadap rata-rata jumlah embrio somatik (Tabel 2). Semua perlakuan dapat merangsang kalus embriogenik rotan tohiti berkembang menjadi embrio somatik dengan rata-rata jumlah embrio antara 3,0-5,6 (Tabel 2). Embrio somatik paling banyak dihasilkan dari perlakuan kombinasi BA $1,0 \mathrm{mg} / \mathrm{l}+2,4-\mathrm{D} 1,0 \mathrm{mg} / \mathrm{l}$ dengan rata-rata jumlah embrio somatik sebanyak 5,6. Penambahan 2,4-D pada konsentrasi 1,0 mg/l ke dalam media tumbuh yang sudah mengandung BA $1,0 \mathrm{mg} / \mathrm{l}$ diduga mendorong terjadinya perubahan keseimbangan kandungan zat pengatur tumbuh di dalam biakan kalus sehingga merangsang peningkatan pembentukan embrio somatik dari kalus embriogenik yang ditumbuhkan. 
Tabel 2. Jumlah embrio somatik rotan tohiti dari kombinasi zat pengatur tumbuh BA dengan 2,4-D

\begin{tabular}{ccc}
\hline $\begin{array}{c}\text { Perlakuan } \\
(\mathrm{mg} / \mathrm{l})\end{array}$ & $\begin{array}{c}\text { Rata-rata jumlah embrio } \\
\text { somatik }\end{array}$ & Visual embrio somatik \\
\hline BA 1,0 + 2,4-D 0,0 & $3,0 \mathrm{c}$ & Batang besar, jelas, daun normal \\
BA 1,0 + 2,4-D 0,5 & $4,0 \mathrm{~b}$ & Batang sedang, pendek \\
BA 1,0 + 2,4-D 0,75 & $4,6 \mathrm{~b}$ & Batang sedang, pendek \\
BA 1,0 + 2,4-D 1,0 & $5,6 \mathrm{a}$ & Batang sedang, pendek \\
\hline
\end{tabular}

Keterangan: Angka yang diikuti oleh huruf yang sama dalam kolom tidak berbeda nyata pada taraf uji 5\%

Perkembangan induksi embrio somatik dari eksplan kalus embriogenik rotan tohiti secara visual sebagaimana disajikan pada Gambar 3. Kalus embriogenik rotan tohiti awalnya berwarna putih bening (Gambar 3a) dan mulai memperlihatkan pertumbuhan dengan ukuran kalus yang bertambah besar menjadi dua kali lipat dalam periode delapan minggu. Hal ini dapat disebabkan oleh beberapa faktor antara lain zat pengatur tumbuh yang ditambahkan ke dalam media tumbuh, tipe kalus dan kondisi biakan. Menurut Zhou et al., (2010) zat pengatur tumbuh memainkan peranan yang sangat penting dalam induksi kalus. Selanjutnya Lim, Ling, dan Hussein (2009) menyatakan bahwa penggunaan zat pengatur tumbuh eksogen penting dalam optimalisasi induksi kalus.
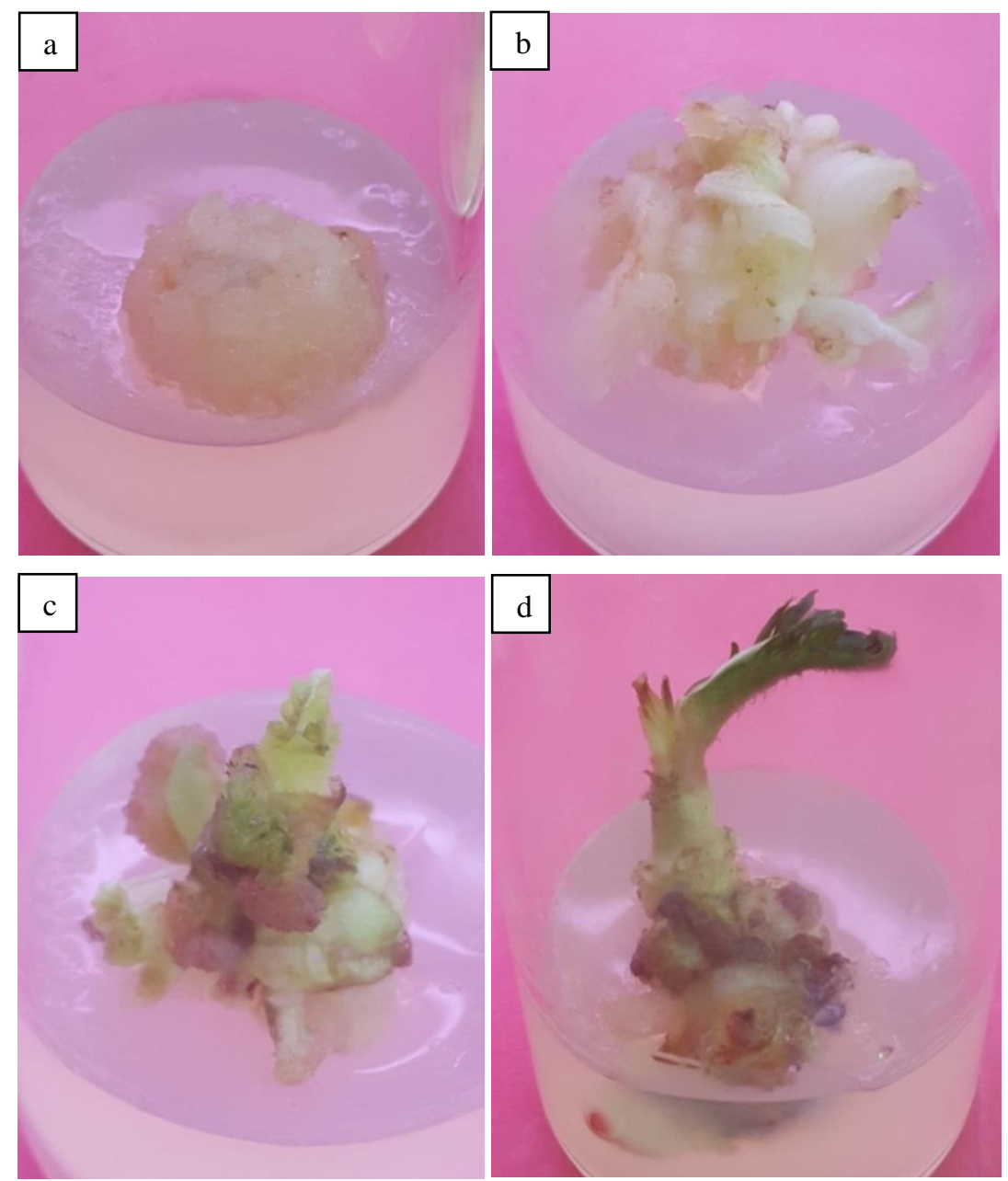

Gambar 3. Perkembangan kalus embriogenik menjadi embrio somatik pada rotan tohiti. Kalus embriogenik (a), embrio fase skutelar (b), embrio fase koleoptilar (c) dan planlet (d) 
Dari pengamatan yang dilakukan selama masa pertumbuhan dan perkembangannya, kalus embriogenik tidak memperlihatkan perubahan warna (Gambar 3a) dan tetap berwarna putih bening sampai terbentuk embrio somatik. Secara visual pembentukan embrio somatik pada rotan tohiti dalam penelitian ini tidak mengikuti pola embriogenesis somatik yang umumnya diawali dengan terbentuknya embrio somatik fase globular. Secara perlahan-lahan, dari sela-sela sel kalus embriogenik yang berwarna putih bening, muncul embrio somatik fase skutelar berwarna putih susu (Gambar 3b) yang berkembang menjadi fase koleoptilar (Gambar 3c), dan selanjutnya menjadi plantlet (Gambar 3d). Perkembangan embrio somatik dalam penelitian ini sesuai dengan penelitian Guan, Li, Fan, dan Su (2016) dan Arnold, Sabala, Bozhkov, Dyachok, dan Filonova (2002) yang melaporkan bahwa tahapan perkembangan embrio somatik pada tanaman monokotil meliputi tahap globular, skutelar dan koleoptilar. Walaupun penelitian lainnya pada jenis tanaman sagu menunjukkan bahwa perkembangan embrio somatik menyerupai fase perkembangan embrio zigotik yang meliputi fase globular, fase hati, fase torpedo dan fase kotiledon (Kasi \& Sumaryono, 2006).

Jumlah embrio somatik yang dihasilkan dari perlakuan BA 1,0 mg/l tanpa 2,4-D lebih sedikit dibandingkan dengan perlakuan kombinasi BA 1,0 mg/l dengan tambahan 2,4-D (Tabel 2) dan mempunyai penampilan visual yang berbeda. Embrio somatik yang dihasilkan mempunyai penampilan yang lebih normal dimana masing-masing organnya dapat dibedakan dengan jelas (Gambar 4a). Selain itu hampir semua embrio yang dihasilkan berukuran lebih besar dibandingkan dengan perlakuan kombinasi BA dan 2,4-D (Gambar $4 b)$.

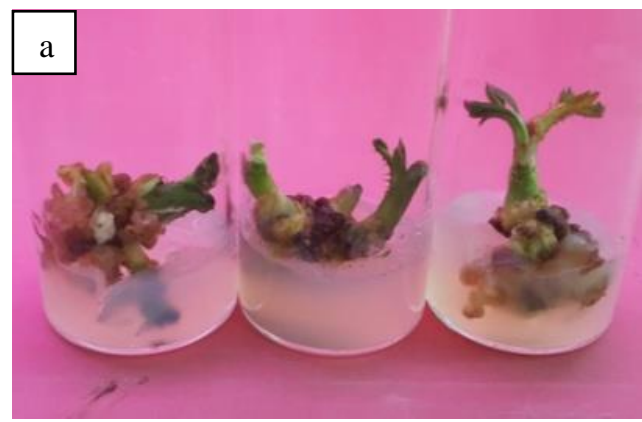

Gambar 4. Embrio somatik rotan tohiti pada perlakuan BA tanpa 2,4-D (a) dan BA + 2,4-D (b)

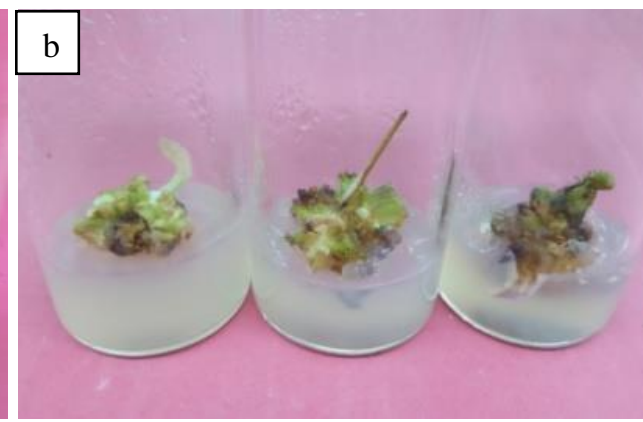

Sumaryono, 2006; Sumaryono, Riyadi, \& Kasi, 2009).

Embrio somatik tahap koleoptilar masih menempel antara satu dengan yang lain (Gambar 3c), tetapi ada batas yang jelas antarembrio somatik sehingga mudah dipisahkan dengan scalpel. Embrio somatik koleoptilar yang sudah dipisahkan dengan tinggi $1,0-2,0 \mathrm{~cm}$ dicoba ditumbuhkan pada perlakuan BA 0,$25 ; 0,5 \mathrm{mg} / \mathrm{l}$ dan $0,75 \mathrm{mg} / \mathrm{l}$. Dari tiga perlakuan BA yang digunakan, perlakuan BA $0,75 \mathrm{mg} / \mathrm{l}$ memberikan tanggapan paling baik untuk pertumbuhan embrio somatik koleoptilar menjadi plantlet (Gambar 5). 

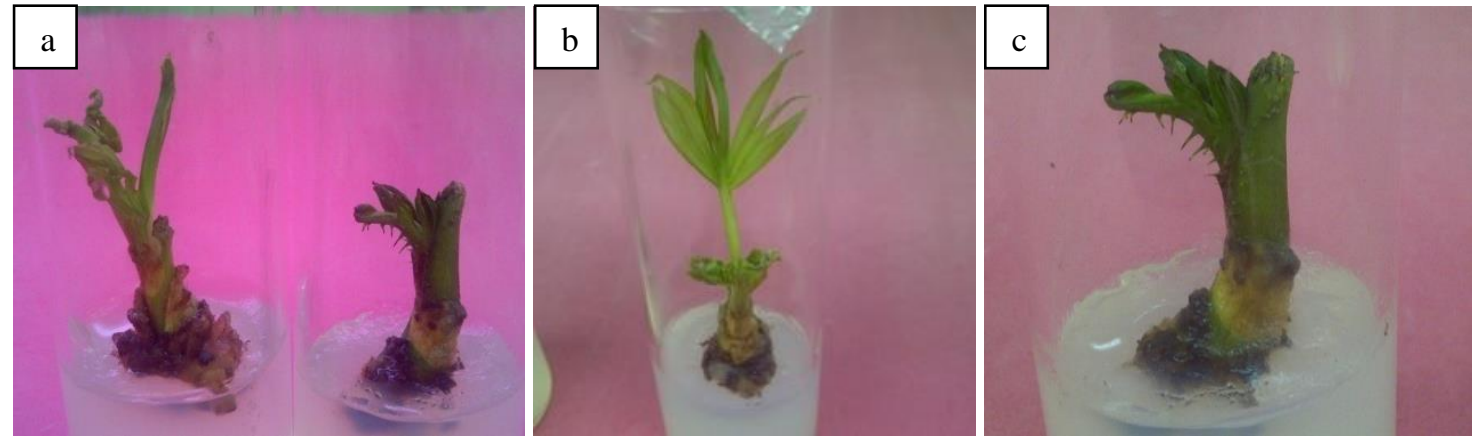

Gambar 5. Perkembangan embrio somatik rotan tohiti menjadi plantlet.Umur 5 minggu (a) dan umur 7 minggu (b dan c)

Tanggap pertama perkembangan lebih lanjut embrio somatik nampak pada munculnya daun baru (pucuk) pada umur 5 minggu setelah ditumbuhkan (Gambar 5a). Pada umur 7 minggu daunnya sudah membuka seperti daun normal (Gambar 5b), namun tidak diikuti dengan pertumbuhan akar. Hal ini diduga disebabkan karena kandungan sitokinin yang ada di dalam jaringan sudah melebihi batas keseimbangan sehingga memberikan pengaruh pada pertumbuhan bagian atas tanaman. Untuk merangsang pertumbuhan akar embrio somatik rotan tohiti dibutuhkan perlakuan lebih lanjut melalui penambahan auksin pada media tumbuh. Hal yang sama juga dilaporkan pada tanaman sagu bahwa untuk induksi akar plantlet diperlukan penambahan auksin pada media tumbuh (Kasi \& Sumaryono, 2006).

\section{KESIMPULAN}

Budidaya jaringan melalui teknologi embriogenesis somatik pada rotan tohiti bisa dilakukan dengan baik. Penambahan zat pengatur tumbuh BA (Benzyl adenine) $1.0 \mathrm{mg} / \mathrm{l}$ pada media dasar Murashige and Skoog (MS) merupakan perlakuan terbaik untuk induksi kalus embriogenik. Jumlah embrio somatik terbanyak ditemukan pada perlakuan penambahan zat pengatur tumbuh kombinasi BA 1,0 mg/l + 2,4-D 1,0 mg/l pada media MS.

\section{UCAPAN TERIMA KASIH}

Ucapan terima kasih disampaikan kepada ibu Dr. Diana Prameswari dari Pusat Penelitian dan Pengembangan Hutan (P3H) Bogor atas kontribusinya dalam penyediaan biji rotan tohiti sebagai sumber tanaman yang digunakan dalam penelitian ini.

\section{DAFTAR PUSTAKA}

Anniasari, E. D., Putri, R. B. A., \& Muliawati, E. S. (2016). Penggunaan BA dan NAA untuk merangsang pembentukan tunas lengkeng dataran rendah (Dimocarpus longan) secara in vitro. Bioteknologi, 13(2), 43-53. https://doi.org/10.13057/biotek/c130201

Arnold, S. von, Sabala, I., Bozhkov, P., Dyachok, J., \& Filonova, L. (2002). Developmental pathways of somatic embryogenesis. Plant Cell ,Tissue and Organ Culture, 69, 233-249. https://doi.org/10.1023/A

Baharuddin, \& Taskirawati, I. (2009). Hasil hutan bukan kayu. Makasar: Fakultas Kehutanan, Universitas Hasanuddin. https://doi.org/10.1017/CBO9781107415324. 004

Eshraghi, P., Zarghami, R., \& Mirabdulbaghi, M. (2005). Somatic embryogenesis in two Iranian date palm cultivars. African Journal of Bitechnology, 4(11), 1309-1312.

Guan, Y., Li, S.-G., Fan, X.-F., \& Su, Z.-H. (2016). Application of somatic embryogenesis in woody plants. Frontiers in Plant Science, 7(June), 1-12. https://doi.org/10.3389/fpls.2016.00938

Hussein, S., Ibrahim, R., \& Kiong, A. L. P. (2006). Somatic embryogenesis: an alternative method for in vitro micropropagation. Iranian Journal of Biotechnology, 4(3), 156161.

Ikeuchi, M., Sugimoto, K., \& Iwase, A. (2013). Plant Callus: Mechanisms of Induction and Repression. The Plant Cell, 25(September), 3159-3173.

https://doi.org/10.1105/tpc.113.116053 
Kalima, T. (2008). Keragaman Spesies Rotan yang Belum Dimanfaatkan di Hutan Tumbang Hiran, Katingan, Kalimantan Tengah. Jurnal Info Hutan, 5(2), 161-175.

Kalima, T., \& Jasni. (2010). Tingkat kelimpahan populasi spesies rotan di hutan lindung Batu Kapar, Gorontalo Utara. Jurnal Penelitian Hutan Dan Konservasi Alam, 7(4), 439-450.

Kalima, T., \& Jasni. (2015). Prioritas penelitian dan pengembangan jenis rotan andalan setempat. In Pros Sem Nas Masy Biodiv Indon (Vol. 1, pp. 1868-1876). Surakarta: Masyarakat Biodiversitas Indonesia. https://doi.org/10.13057/psnmbi/m0108220

Kasi, P. D., \& Sumaryono. (2006). Keragaman morfologi selama perkembangan embrio somatik sagu (Metroxylon sagu Rottb.). Menara Perkebunan, 74(1), 43-51.

Kusdi, \& Muslimin, I. (2008). Perkecambahan benih rotan manau (Calamus manan Miq .) berdasarkan berat benih dan jenis media tabur. Info Hutan, V(4), 347-354.

Lestari, E. G. (2011). Peranan Zat Pengatur Tumbuh dalam Perbanyakan Tanaman melalui Kultur Jaringan. Jurnal AgroBiogen, 7(1), 63-68. https://doi.org/10.21082/jbio.v7n1.2011.p6368

Lim, Z. X., Ling, A. P. K., \& Hussein, S. (2009). Callus Induction of Ocimum sanctum and Estimation of Its Total Flavonoids Content. Asian Journal of Agricultural Sciences, 1(2), 55-61.

Muchtar, H., Winata, L., Wattimena, G. ., \& Yahya, S. (1997). The Effect of Two Kind of Cytokinin (BAP and Kinetin) and Auxin on Multiplication Formation in Rattan Manau (Calamus manan Miquel) by in vitro Technicque. Retrieved May 2, 2018, from http://repository.ipb.ac.id/handle/123456789/ 45250

Oetami, R. F. (2015). Kombinasi embriogenesis langsung dan Tak Langsung pada Perbanyakan Kopi Robusta. Warta Pusat Penelitian Kopi Dan Kakao Indonesia, 27(2), $1-5$.

Pribadi, H. (2012). Kajian ekonomi pengembangan usaha industri mebel rotan di kota Palu Provinsi Sulawesi Tengah (Pendekatan analitikal SWOT dan liniear programming). Jurnal Hutan Tropis, 13(2), 111-120.
Puhan, P., \& Rath, S. P. (2012). Induction, Development and Germination of Somatic Embryos from in vitro Grown Seedling Explants in Desmodium gangeticum L.: Medicinal Plant. Research Journal of Medicinal Plant, 6(5), 346-369.

Rusdianto, \& Indrianto, A. (2012). Induksi kalus embriogenik pada wortel (Daucus carota L.) menggunakan 2,4-Dichlorophenoxy Acetic Acid (2,4-D). Jurnal Bionature, 13(2), 136140.

Sumaryono, Riyadi, I., \& Kasi, P. D. (2009). Clonal Propagation of Sago Palm (Metroxylon sagu Rottb.) through Tissue Culture, 2(1), 1-4. Retrieved from https://www.researchgate.net/profile/Pauline_ Kasi/publication/236004883_Clonal_propaga tion_of_sago_palm_through_tissue_culture/li nks/02e7e51591005e6462000000.pdf

Vondráková, Z., Krajňáková, J., Fischerová, L., Vágner, M., \& Eliášová, K. (2016). Physiology and role of plant growth regulators in somatic embryogenesis. In J. M. B. and H.-K. M. Yill-Sung Park (Ed.), Vegetative Propagation of Forest Trees (pp. 123-169). Seoul, Korea: National Institute of Forest Science (NIFoS).

Winarni, E., Fitriani, A., Purnomo, \& Panjaitan, S. (2017). Daya kecambah benih rotan jernang (Daemonorops draco Blume) dengan berbagai perlakuan perendaman dalam air. Jurnal Hutan Tropis, 5(2), 120-126.

Witono, J. R. (1999). Konservasi rotan Indonesia di Kebun Raya Bogor. In Prosiding seminar hasil-hasil penelitian ilmu hayat (pp. 230242). Bogor.

Zang, Q., Zhou, L., Zhuge, F., Yang, H., Wang, X., \& Lin, X. (2016). Callus induction and regeneration via shoot tips of Dendrocalamus hamiltonii. SpringerPlus, 5:1799, 1-7. https://doi.org/10.1186/s40064-016-3520-7

Zhou, Q., ZH, J., TD, H., WG, L., AH, S., Dai, X., \& Z, L. (2010). Plant regeneration via somatic embryogenesis from root explants of Hevea brasiliensis. African Journal of Biotechnology, 9(48), 8168-8173. https://doi.org/10.5897/AJB10.969 